\title{
“Why not love our language and our culture?" National rights and citizenship in Khrushchev's Soviet Union
}

\author{
Krista A. Goff* \\ History Department, University of Miami, Coral Gables, USA
}

(Received 30 September 2014; accepted 30 September 2014)

\begin{abstract}
This paper highlights campaigns for national rights among two non-titular communities in the Soviet Union and places them in local historical contexts. Drawing on archival sources and oral history interviews, the author not only delves into the campaigns themselves, but also explores broader debates about the nature of Khrushchev's Thaw and Soviet citizenship, which was far from an empty concept in the Khrushchev era. Petitioners invoked discourses that indicate both an awareness of national rights and an expectation of the state's obligation to protect them. Oral history interviews with surviving petitioners and community members support the notion that petition language can serve as a reflection of how petitioners viewed their place in Soviet society and interpreted the Soviet citizen contract.
\end{abstract}

Keywords: Soviet nationality policy; Khrushchev; citizenship; Soviet history; nationality politics; post-World War II era

We love the languages of all the republics of our Soviet Union and their culture, why not love our language and our culture...

Why with such bitterness do they forbid us from studying in our native language ...

Why do they close our schools and if someone dares to protect the native language and native school he suffers persecution and all sorts of coercion?

-Anonymous petitioners from Azerbaijan (Zayam and Tasmali villages, Qax region) in a letter addressed to Nikita Khrushchev, first secretary of the Communist Party of the Soviet Union (CPSU), in 1962. ${ }^{1}$

During Khrushchev's term as first secretary, nationality-based grassroots movements pressured Soviet officials to recognize and protect rights that had been suppressed or violated. Some Chechens and Ingush, for example, used letter campaigns, work stoppages, demonstrations, and unauthorized migrations to demand that they be allowed to leave their places of exile and return home to the Caucasus. Crimean Tatars also extensively petitioned Khrushchev and other Party leaders for permission to return to Crimea and regain rights that were stripped from them when they were deported. ${ }^{2}$

The Chechen, Ingush, and Crimean Tatar movements have attracted scholarly attention, but nationality-based activism in the Khrushchev years extended beyond the unique exile paradigm that their stories represent (on the Chechens, Ingush, and Crimean Tatars, see, for example, Allworth 1998; Fisher 1978; Kozlov 2002; Pohl 2002; Uehling 2004;

*Email: kgoff@miami.edu 
Westren 2012; Williams 2001). This indicates that the extreme conditions of the special settlement regime were not the only factors emboldening grassroots mobilization and national contention at this time. More specifically, and as the epigraph demonstrates, Azerbaijan was another site where national movements displayed dissatisfaction with both contravened national rights and the use of intimidation as a tool of social control. This article looks at two communities in Azerbaijan - the Georgian-Ingilo and Lezgins - to argue that Khrushchev's "Thaw" had real meaning in terms of how Soviet citizens conceptualized their rights, expressed demands, and engaged with the state. ${ }^{3}$

Georgian-Ingilo settlements are found in three Azerbaijani regions that border eastern Georgia - Balakan, Zaqatala, and Qax. The population includes both Muslim and Christian settlements. As this article shows, local officials often treated and categorized these communities differently. It is therefore difficult to say how many Georgian-Ingilo lived in the Azerbaijan SSR (AzSSR), but a loose estimate is in the low tens of thousands. ${ }^{4}$ Lezgins, meanwhile, lived compactly in many of the Azerbaijani regions that bordered Dagestan, but significant Lezgin communities also could be found elsewhere in the republic, including in Baku. Soviet censuses are also unreliable for this population, but there were significantly more Lezgins than Georgian-Ingilo in Soviet Azerbaijan. State statistics for Azerbaijani Lezgins ranged from 111,666 in the 1939 census to 98,211 in 1959 and 137,250 in 1970 (Tsentral'noe statisticheskoe upravlenie 1963, 134-135, 1973, 263; Vsesoiuznaia perepis' naseleniia 1939 goda 1992, 71).

This article begins in the 1940s to illustrate the prehistory of Khrushchev-era GeorgianIngilo and Lezgin movements and to better map shifts in post-Stalin legal consciousness and state-citizenry relations. I foreground the Georgian-Ingilo example because of the history of Georgian interventionism in Georgian-Ingilo affairs in Azerbaijan. This lends a unique element to this case study, but it also allows me to complement the oral history interviews that I gathered in Azerbaijan, Georgia, Makhachkala, and Moscow with archival materials. ${ }^{5}$ The Lezgin case is not as richly documented, but is invoked here to broaden the significance of the Georgian-Ingilo movement and to highlight the importance of kin republic relationships in contests over non-titular national rights.

Petitioning assumed a commonplace role in Russian administrative and legal cultures long before the Soviet period. It was an unexceptional component of the Russian imperial rights regime, and individuals engaged with the empire's estate-based, differentiated rights through petitions and the courts (Burbank 2006). ${ }^{6}$ In Soviet historiography, studies of Soviet citizenship and petitions focus on the Stalin era. In this literature, petitions often have been used to document resistance (for example, Chulos 1997; Fitzpatrick 1994; Viola 1996), or to illustrate how Soviet citizenship was used as a weapon of repression or fell short of universalized measures of citizenship. ${ }^{7}$

I do not consider the Georgian-Ingilo and Lezgin petitions cited here to be evidence of resistance to the Soviet regime or of the failure of Soviet citizenship. Rather, activists used petitions and other means of protest to challenge internal borders of citizenship and to gain observance of constitutionally guaranteed national rights that were violated by everyday practices. Although branded nationalists and hooligans by local officials, they employed largely sanctioned channels to agitate for the realization of Leninist principles and displayed a contractual understanding of political life in the USSR. ${ }^{8}$ Acts that could be framed or understood as resistance by historians or, indeed, by Party officials thus were often more anti-policy than anti-Soviet.

Further, rather than measuring Soviet citizenship as real, handicapped, or fictive in contrast with other models, I strive to judge it on its own merits. ${ }^{9}$ Soviet citizenship was not a zero-sum practice in which rights were or were not fulfilled, but a productive concept that 
facilitated myriad social possibilities. Constitutional guarantees of economic, cultural, social, and political equality for all citizens irrespective of their nationality, as well as affirmations of these rights in revered tracts written by Soviet leaders, may not have always been upheld, but their existence created possibilities for rights negotiation and contention. Through the disputes described in this article, members of the Lezgin and GeorgianIngilo communities testify to their investment in Soviet citizenship.

\section{Conceptualizations of rights from the 1940s to the 1960 s}

\section{Stalin-era activism}

Long after the Soviet national question was supposedly solved, local residents, activists, academics, politicians, and others continuously negotiated national rights in the USSR. Looking across political eras allows us to see change over time and to adopt a more nuanced understanding of rights and, more importantly, conceptualizations of rights. Thus, in order to clarify the specificities of the grassroots movements that emerged in the 1950s, it is helpful to begin with a brief exploration of late Stalin-era GeorgianIngilo and Lezgin complaints.

An important differentiating variable between the Georgian-Ingilo and Lezgin populations in Azerbaijan is that the Georgian-Ingilo shared a kin republic relationship with the neighboring Georgian SSR, whereas the larger Lezgin population experienced a more muddled connection to the Dagestan Autonomous Soviet Socialist Republic, where Lezgins were one of several dominant nationalities (on kin states, see Brubaker 1996). Kin republic relations complicated minority affairs in the Soviet Union and created an informal hierarchy of non-titular populations. In comparing the Lezgins and Georgian-Ingilo, it appears as though kin republic support could result in more traction with rights complaints and in better access to national-cultural resources, including native-language schools and publications. The special relationship that Georgians and Georgian leaders enjoyed with Stalin also markedly advanced the claims of Georgian-Ingilo activists in the 1940s.

The greatest divergence between the Georgian-Ingilo and Lezgins came at the close of the 1930s. When Union-wide education reforms in 1938 precipitated the closure of many non-titular schools, primary school instruction in the AzSSR was reduced from over a dozen languages to four - Azerbaijani (the titular language of Azerbaijan), the titular languages of the neighboring Armenian and Georgian SSRs, and Russian. Lezgin schools, meanwhile, were closed even though there were far more Lezgins than Georgian speakers in Azerbaijan. This highlights how Lezgins occupied a middle ground between titularity and non-titularity. In Dagestan, there was no single "titular" nationality. Rather, a number of specified nationalities, including the Lezgins, experienced national cultural support and shared political representation. The status of the Lezgin nationality in Dagestan was thus somewhat akin to that of titular populations in SSRs, but, as evidenced by Lezginlanguage school closures in Azerbaijan, did not carry comparable weight outside of Dagestan.

The Georgian-Ingilo community, however, was not without its own complications. The national categorization of the population was deeply politicized, in large part due to contestation over the relationship between the Georgian-Ingilo population and Georgia. Georgian-language programs and resources held somewhat steady in Christian Georgian-Ingilo communities, but continuously contracted and expanded in Muslim villages. For example, although Azerbaijan's Georgian-language schools and sectors were slated to stay open after the reorganization of national schools in 1938, schools in Aliabad, Mosul, and other 
Muslim Georgian-Ingilo communities were converted to the Azerbaijani language in the early 1940 s. $^{10}$

After these school conversions, incited Georgian-Ingilo activists and Georgian politicians fought for redress. Activism in the 1940s and early 1950s was defined mainly by the efforts of two individuals - Georgian Communist Party First Secretary Kandid Charkviani and Georgian-Ingilo academic Georgii Gamkharashvili. ${ }^{11}$ Gamkharashvili was from Qax, but spent his professional career working in Georgian academic institutions. From his base in Tbilisi, he sent numerous letters and reports to Stalin, Charkviani, and other politicians to complain about the Georgian-Ingilo situation in Azerbaijan and to request that Balakan, Zaqatala, and Qax be transferred to the Georgian SSR. He also traveled to Moscow to try and petition Stalin in person. ${ }^{12}$

Gamkharashvili apparently elicited a response from Stalin and is valorized by many Georgians and Georgian-Ingilo for his efforts. ${ }^{13}$ In Charkviani's memoir, for example, he recalls that Gamkharashvili "worked all his life to have his native region returned to Georgia" and that, after Gamkharashvili met with Stalin, Charkviani was ordered to work with Azerbaijani First Secretary Mir Cafar Bagirov to improve the situation in Georgian-Ingilo communities (Charkviani 2004, 500-503). ${ }^{14}$ During his negotiations with Bagirov and Stalin, Charkviani secured guarantees to improve Georgian education and conditions in "Ingilo" villages. 15

Charkviani, and his close relationship with Stalin, certainly helped advance GeorgianIngilo complaints in the $1940 \mathrm{~s}$, but this case also speaks more broadly to the privileged status that Georgians and Georgia enjoyed in the Stalin years. Stalin stopped short of approving Charkviani's request to transfer Zaqatala, Qax, and Balakan to the Georgian SSR, but he did enable Georgian elites and officials to play a disruptive role inside Azerbaijan on behalf of the Georgian-Ingilo. This unique inter-republic interference engendered frustration among Azerbaijani officials who complained about Georgian meddling and the negative influence that Georgians had on the "Ingilo" population. ${ }^{16}$

The Lezgin story, meanwhile, simmered until the late 1950s. Available archival records in Dagestan, Moscow, and Azerbaijan, as well as oral history interviews, indicate that some Lezgins in Azerbaijan petitioned to gain expanded recognition of their national rights in the Stalin era, but their complaints found less traction. In 1936, for example, a group of Lezgins from Khachmas sent a letter to Pravda proposing that the new constitution unify Dagestani and Azerbaijani Lezgins to further their economic and national development. ${ }^{17}$ The letter was forwarded to the Central Executive Committees of Azerbaijan and Dagestan and both were requested to inform the Central Executive Committee of the Soviet Union about the merits of creating a Lezgin okrug or oblast. It is unclear what happened afterward. ${ }^{18}$ Extrapolating from a Khrushchev-era complaint letter, it appears that a separate group of Lezgins complained to Bagirov in the 1940s about "lezgi pulu" (Lezgin money), a so-called informal tax levied against Lezgin students. ${ }^{19}$ The Lezgin case thus provides some examples of small group organizing in the Stalin era - and of the willingness of some citizens to engage in rights negotiations with the state - but no significant examples of increased national rights fulfillment among Lezgins at this time. The Georgian-Ingilo case, meanwhile, shows that individuals could be successful when they traded on personal relationships and kin republic connections in rights negotiations.

\section{Khrushchev-era grassroots campaigns}

By the end of the 1950s, national movements were coalescing not only in non-titular communities in Azerbaijan, but also among titular elites. De-Stalinization created new 
opportunities for national activists to push for the realization of ascribed, but unfulfilled, national rights. This article focuses on the Georgian-Ingilo and Lezgin movements, but important changes in republican governance correspond with the trajectory of non-titular claims in the 1950s and early 1960s.

The relationship between Georgian-Ingilo activists and the Georgian SSR leadership appears to have become more distant after 1952, when Charkviani was deposed as a consequence of the Mingrelian Affair. ${ }^{20}$ Stalin's death the following year and the rise of a new Azerbaijani leadership cohort in 1954 also precipitated significant changes in the local power dynamic. ${ }^{21}$ Although titular populations were comparatively privileged within the boundaries of "their" republics, members of these communities sometimes chafed at Moscow's control over republican affairs and at the all-Union prestige and hegemony of the Russian language and culture.

The short-lived leadership (1954-1959) of the men who replaced Bagirov's government in Azerbaijan - Mirza Ibragimov, as head of the Supreme Soviet, and Imam Mustafaev, as first secretary of the Communist Party - has been characterized as a period of development for Azerbaijan's national identity. Ibragimov and Mustafaev oversaw a series of policies aimed at expanding Azerbaijani titular rights and increasing the status of the Azerbaijani language in the republic. Symbolizing the recursive nature of national discontent in the Soviet Union, Azerbaijani historian Camil Hasanli argues that it was only after 1956 - when Ibragimov introduced a controversial constitutional amendment making Azerbaijani the official language of the republic - that the Azerbaijani nation "felt itself master in its house" (Gasanly 2009, 616). ${ }^{22}$ Their nationalizing government did not last long, however. Kremlin officials precipitously ushered Ibragimov (1958) and Mustafaev (1959) out of office and denounced Musatafaev's leadership for economic, political, and ideological deviations (Bakinskii Rabochii, July 11, 1959; Balaev 2005, 124).

In his memoir, Charkviani alludes to a dark trajectory for the Georgian-Ingilo population after his dismissal (2004, 500-503). As evidence for this sentiment perhaps, the Georgian-language schools that Charkviani helped to reopen in Muslim villages in the late 1940s were converted to the Azerbaijani language over the course of Ibragimov and Mustafaev's terms in office - in Tasmali and Zayam in 1954, in Aliabad in 1957, and in Ititala the following year. ${ }^{23}$ Despite Charkviani's bleak assessment and the undeniable change in power politics after Stalin's death, Georgian-language school closures in the 1950 s provoked a strong and varied response. How did we get here from the more dispersed, clientelist, and individualized efforts that defined the late Stalin period?

Azerbaijan Communist Party records indicate that Baku officials received a large number of collective petitions and complaint letters from Georgian-Ingilo communities between the mid-1950s and the early $1960 \mathrm{~s} .{ }^{24}$ The archive is littered with petitions and government reports about the closure of Georgian-language schools and associated issues such as underreported census numbers and poor economic, political, and cultural resources and opportunities in Georgian-Ingilo communities. In contrast with Gamkharashvili's letters in the Stalin era, several dozen Georgian-Ingilos collectively signed some of these later petitions and sent them from both student dormitories in Tbilisi and villages in Balakan, Zaqatala, and Qax. Further, according to government reports, activism extended beyond petition writing at this time. ${ }^{25}$

These activists encountered opposition from both local officials and other members of the community. This article focuses on Georgian-Ingilo and Lezgin rights claims because of the story that they tell about Soviet citizenship, but many people in non-titular communities supported, or at least were indifferent to, enrolling their children in Azerbaijani school sectors. Preference among minorities for titular- or Russian-language learning existed 
throughout the USSR because native-language education in minority communities could make it more difficult for minorities to integrate into broader social contexts. For example, one Georgian-Ingilo woman linked Azerbaijani-language knowledge to status:

Every population has an elite group. My father's family was considered among this group and they always spoke Azerbaijani even though they were natives of [a Muslim Georgian-Ingilo village]. I thus was sent to Azerbaijani school, although I learned Ingilo too because my mother would use it when she was upset with us kids. (Author interview, Azerbaijan, July 2008)

Other interviews drew attention to different issues, such as difficulties participating in local political meetings conducted in the Azerbaijani language and limited employment opportunities for non-Azerbaijani speakers (author interviews, Azerbaijan and Georgia, 20102011).

In Azerbaijan, local officials often claimed that they converted Georgian-language schools and school sectors to Azerbaijani in response to local demand for instruction in the Azerbaijani language. For example, in 1959, Azerbaijan Communist Party Secretary Bairamov reported to Moscow that, "Ingilo" from Ititala, Aliabad, Zayam, and Tasmali in organized meetings, as well as in conversations held in collective farms and field camps, "resented the disgraceful behavior of the petition authors." ${ }^{26}$ A. Mansurov, secretary of the Balakan district committee, echoed this sentiment when he informed Baku officials that Ititala residents and teachers demanded the unmasking and punishment of the anonymous petitioners writing provocative letters. ${ }^{27}$

Nonetheless, the tone and content of the Azerbaijan Communist Party's stance on Georgian-Ingilo issues began to shift after Mustafaev's demotion in 1959. For example, that July, the Qax-Gurcu soviet proposed adding Azerbaijani-language instruction to local Georgian-language school curriculums. ${ }^{28}$ Local officials argued that Georgian-Ingilo students needed to know Azerbaijani if they wanted to live functional lives in the AzSSR. A few months later, however, the Central Committee of the Azerbaijan Communist Party rejected the proposal as "incorrect both in form and in substance" and censured the local secretary. ${ }^{29}$

In an indication of how widespread discontent had become in Georgian-Ingilo communities, by 1961 multiple government officials were willing to acknowledge that measures needed to be taken in order to "remove existing resentment" in the region. ${ }^{30}$ After M. Mexti-zade, from Azerbaijan's Ministry of Enlightenment (MinPros), visited the area in 1961, for example, he proposed opening a Georgian sector in the Zaqatala internat (boarding school), supported the practice of parallel Azerbaijani- and Georgian-language sectors in schools, and reformulated the use of Azerbaijani-language preparatory classes for Georgian-Ingilo children preparing to enter the school system. Mexti-zade closed his recommendations with the hope that an authoritative and productive investigation would put an end to "unhealthy conversations" in the region. ${ }^{31}$ That same year, an Azerbaijan Communist Party decree about schools for "Ingilo" in Zaqatala, Balakan, and Qax reversed the post-Stalin trend of Georgian-language school closures in this corner of Azerbaijan. The decree apportioned additional support for Georgian-language schools and assured "Ingilo" parents of their right to choose the language of education for their children. By the following year, Azerbaijan's MinPros had opened new Georgian sectors in some Muslim Georgian-Ingilo villages and, with the assistance of Georgia's MinPros, moved to improve the educational infrastructure in local Georgian schools. ${ }^{32}$

Although Azerbaijan's MinPros determined that numerous educational inadequacies had been "eliminated," 33 the central committees of the CPSU and the Azerbaijan Communist Party continued to receive requests from Georgian-Ingilo petitioners for the 
improvement of local economies, electrification of their villages, and access to Georgianlanguage radio transmissions. Some petitioners further argued that school and government officials were undermining Party decrees and disrupting the re-Georgianization of local schools. $^{34}$

An official report dismissed ongoing problems as the work of "a small group of Ingilo students" studying in Georgia, but every indication is that tensions continued to simmer. ${ }^{35}$ In 1966, a new Party report noted that many parents and teachers were upset about latearriving Georgian-language educational literature from Georgia, and concluded that this and several other aspects of Georgian-language education remained deficient in Zaqatala, Qax, and Balakan. ${ }^{36}$ The Central Committee of the Azerbaijan Communist Party adopted the recommendations of the report authors and drafted another formal decree in March 1966 for the Georgian-Ingilo communities. The new decree declared the Party's intention to strengthen the material conditions of "Ingilo" schools; reliably acquire textbooks and other literature for the schools; make it easier for these students to enroll in post-secondary Azerbaijani educational institutions; honor a local Georgian-language school and teachers with a diploma from the Supreme Soviet of the Azerbaijan SSR; and improve ideologicalpolitical work in the "Ingilo" community. ${ }^{37}$

Azerbaijani officials were right that Georgian-Ingilo students in Tbilisi assumed a conspicuous role in national rights agitation at this time, but these individuals were building on a broader movement. Letters sent during this post-Stalin period of rights negotiation originated from multiple villages in Azerbaijan and were signed by both Georgian-Ingilo students studying at Tbilisi universities and locals living in Azerbaijan. ${ }^{38}$ In the course of a decade, Georgian-Ingilo activism transformed from a project of elites (Charkviani) and individuals (Gamkharashvili) to more widespread grassroots agitation.

Furthermore, it would be a mistake to dismiss the student petitioners as agents of Georgian nationalists because of their connections to the Georgian SSR. To be sure, students in Tbilisi were introduced to an environment rich in Georgian cultural resources and to people who supported their activism, including Gamkharashvili and others. While Georgia may have given these students the opportunity to gather and organize, they were not mere puppets of Georgian nationalists. As one petitioner recounted in an interview, he believed in the national rights articulated in Stalin's Marxism and the National Question and the Soviet constitution. To this day he freely quotes from both texts. According to him, it was through a language of legality and rights - borrowed from the Soviet constitution, "Leninist nationality policy," and Khrushchev's call for a "return to socialist legality" in 1956 - that he learned how to articulate his own beliefs. ${ }^{39}$ Displaying reverence for the center and engagement with Soviet ideology, he blamed errant local officials for proscriptions of national rights and disloyalty to Soviet principles. He was convinced that Moscow officials would intervene once they found out what was happening in his community (author interview, Azerbaijan, November 2010). The routine transgression of his ascribed national rights failed to destroy the centrality of Soviet ideals in his understanding of the way that things should work.

The evolution of activism in Georgian-Ingilo communities bears a striking resemblance to Lezgin activism in the late 1950s. In 1959, Zabit Rizvanov, a Lezgin poet and native of Qusar, and a few others organized an informal group in Qusar called Rikhin Gaf (РикІин гаф). ${ }^{40}$ Rikhin Gaf was comprised mainly of writers, poets, musicians, and teachers who would gather to discuss one another's creative works. As one former participant reminisced, however, eventually they decided that it was "necessary to re-establish their forfeited national rights" (author interview, Azerbaijan, May 2011). According to Rizvanov, in 1960, Rikhin Gaf members turned their attention to the rehabilitation of the Lezgin 
language and culture in Azerbaijan (undated samizdat, 115). Like Gamkharashvili, they traveled to Moscow to present their demands to central authorities. They also circulated collective petitions outlining their requests to officials in Moscow and Baku. Rikhin Gaf was not necessarily isolated in Qusar, however. Lezgin petitioners from other parts of Azerbaijan also advanced claims and demands similar to those of Rikhin Gaf participants.

Just one year after the decree on Georgian-language schools in May 1961, the Central Committee of Azerbaijan's Communist Party adopted a parallel, but scaled down, decree for Lezgins - "About the improvement of cultural and everyday conditions for the population of Lezgin nationality living in Qusar region of the Azerbaijan SSR." AzMinPros was ordered to organize Lezgin-language sectors in Qusar for grades one through four by 1 September 1962; the Ministry of Culture and state publisher were ordered to acquire Lezgin typeset to begin printing a few pages of local newspapers in the Lezgin language and distribute Lezgin-language papers from Dagestan in Azerbaijan; and the Ministry of Culture was directed to create Lezgin ensembles and a Lezgin National Theater in Qusar. ${ }^{41}$ Two months later, the first secretary of the Azerbaijan Writers' Union informed the Central Committee of the Azerbaijan Communist Party that he would take measures to incorporate more Lezgin writers into the Union and to support the publication of Lezgin poems, prose, and stories. ${ }^{42}$

As in the case of the Georgian-Ingilo, the decree seemed to encourage Lezgin dialogue with the state. After the decree was adopted, Lezgins from other regions of the AzSSR submitted requests to expand its geographical scope. For example, in a handwritten note from Siazan, a town roughly equidistant from Baku and the Dagestan border, a Siazanneft worker wrote that he was happy to receive radio transmissions in Russian, Armenian, and Azerbaijani, but also wanted access to radio transmissions and newspapers in his native language. ${ }^{43}$ In February 1963, a commission visited Qusar to investigate new claims. The commission concluded that the Party needed to conduct political work among Lezgins and find ways to improve Lezgin cultural and economic life.

It is productive to contrast the Lezgin experience with that of the Georgian-Ingilo because, viewed alongside one another, the two cases complicate charges of exceptionalism. The nearly simultaneous, yet autonomous, Lezgin and Georgian-Ingilo movements illustrate that new forms of social organization gained currency in the Khrushchev era. Salient differences between the two cases also are productive. For example, although the Lezgin population far outnumbered that of the Georgian-Ingilo, their activism achieved more limited results. One key explanatory variable is the kin republic factor. Lezgin coethnics in Dagestan were one of several groups considered "titular" in the Dagestan ASSR, but Georgians were the single titular population of the Georgian SSR. Thus, Lezgin activists sometimes relocated to Dagestan, but lacked the social and institutional support that someone like Charkviani brought to the Georgian-Ingilo case (author interview, Dagestan, July 2013).

\section{The language of dissent}

The shift from fairly autonomous individuals to popular movements in the 1950s is one indication of how activism among Lezgin and Georgian-Ingilo activists changed over time. New relations between state and society in the Khrushchev era are also represented through the language that Khrushchev-era activists invoked in their petitions. The intention here is not to imply that there was a linear progression of writing styles, or to assert a sharp break between Khrushchev-era petitions and those that came before. Writing styles carried 
over from one political era to the next, and contemporaneous petitioners often invoked different styles and strategies when appealing to the authorities. ${ }^{44}$

Nonetheless, there are marked differences between the examples that we have here from the late Stalin era and the Khrushchev years. Letters written by Gamkharashvili and his contemporaries mirror many of the pre-Soviet tropes that scholars have identified in supplicant letters from the 1920s and 1930s. Although his or her language might be deceiving, a supplicant's relationship to power also implied the existence and expectation of a social contract. Alexopoulos argues that officials made clear a formula for rehabilitation at this time demonstrate one's dedication and usefulness to the regime - but many ignored it in favor of a non-Soviet presentation of the "pathetic self," which also met with success $(1997,119$ 120). Sheila Fitzpatrick similarly analyzes the language of letters and petitions to define what it meant to be a supplicant (versus a citizen). According to Fitzpatrick, supplicants performed as subjects, called for justice rather than legal rights, and conceived of authority figures as "beloved father[s]" $(1996,92) .{ }^{45}$ Expository autobiographies also were invoked as complainants sought to justify their "Soviet credentials" to the authorities judging their letters.

Gamkharashvili's numerous examples neatly fit into this classification. His primary goal was to convince the authorities - and Stalin in particular - that the Azerbaijani government discriminated against Georgian-Ingilo communities and they would be better served in Georgia. However, rather than invoke specific laws to argue why Georgian schools should be opened, Georgian-Ingilo kolkhoz lands should be kept separate from Azeri kolkhozes, or territories should be transferred between republics, Gamkharashvili settles on vague pronouncements about "unjust" and "outrageous" policies and mistakes that caused Zaqatala, Qax, and Balakan to end up in the Azerbaijan SSR. ${ }^{46} \mathrm{He}$ references "Soviet policy," the spirit of "Lenin and Stalin's teachings," and the "foundations of the Soviet constitution," but fails to develop claims to specific policies or laws. ${ }^{47}$

Further, he positions himself - and the Georgian-Ingilo in general - as supplicants begging for merciful help from the protectors of Georgian justice. In one passage he writes: "Only a sincere desire to help my suffering countrymen, and to fulfill my duty to them, makes me again raise this tragic question of Georgians, [who] mistakenly and wrongly ended up outside Georgian Soviet control." 48 He pleads with Charkviani and other officials, and appeals to them as the people governing "the life of the Georgian tribe [plemen]. ${ }^{, 49}$ His letters to Stalin reinforce this approach:

Knowing the exceptional burden of your varied and difficult governmental affairs, and given your utter lack of free time, nevertheless please allow me to appeal personally to you with the request to set aside 20 minutes for the accompanying memorandum ... The memorandum concerns the extremely abnormal and difficult life of Azerbaijani Georgians (Ingilo). The intolerableness of their situation deserves your attention ... In the present historical period, only your personal intervention can correct their fate. ${ }^{50}$

Gamkharashvili also frequently describes his biographical appropriateness for the task at hand, asserting that he is a native of Qax, graduated from an institute in Moscow, and has worked in Georgia for a long time. ${ }^{51}$

Georgian-Ingilo authors of contemporaneous complaint letters echo Gamkharashvili's writing style. For example, Archil Dzhanashvili also presents his Soviet biography and justifies his qualifications as a petitioner - he is an "Ingilo" from Qax who works as an academic in Tbilisi, but regularly visits "Saingilo." Praising the Stalin constitution and the successes of Soviet power, he also assumes a deferential attitude in his lengthy appeals to Charkviani and other Georgian officials. ${ }^{52}$ 
Petitions written by Georgian-Ingilo in the late 1950s and 1960s not only display some continuity with late Stalin-era efforts, but also reflect shifts in tone and argumentation. Available documents indicate that these later writers regularly emphasize the legal baseline of their claims to equality and invoke a direct, confident, and authoritative tone. Some of the phrases and words that appear across multiple letters and petitions include "unlawful;" "right;" references to violations of named decrees and constitutional articles; claims about specific anti-Soviet and anti-Leninist nationality practices; explanations of the "legality" of petitions; and criticism of behaviors akin to the cult of personality denounced at the Twentieth Party Congress.

In one petition sent to the Soviet Minister of Culture in 1962, signatories from Aliabad argue that local officials failed to implement the 1961 decree:

The current chairman of the raiispolkom [district executive committee], Madiashov, in every possible way hinders the development of Georgian schools in our region. Despite the fact that there is a decree of the TsK AzKP [Central Committee of the Azerbaijan Communist Party] from 19 May 1961 about the restoration of Georgian schools in the villages where Georgian-Ingilo live, the regional leadership does not comply with this decree. To this day, there is agitation against the admission of Georgian Muslim Ingilos to Georgian schools. ${ }^{53}$

In another long, collective letter from 1962, the petitioners write, "We ... demand the restoration of Leninist norms in schools and in many other issues. Our demand is fully lawful, and it cannot be considered a dishonor and cannot be called demagoguery." 54 Another individual petitioner from Aliabad requested that Vali Akhundov, the first secretary of the Central Committee of the Azerbaijan Communist Party, help the "Ingilo" population and informed him that if a commission found inconsistencies between his claims and the "facts," then he was prepared to answer the commission with applicable legal articles. ${ }^{55}$

To these writers, the legal and political systems equally produced expectations of meaningful and stable national rights. They employed arguments based on constitutional articles, decrees, and precedent to argue their case in political channels, and to try and produce new legal norms and configurations. In so doing, they challenged the practices of local officials, detailed how these officials were in violation of both Soviet law and Soviet values, and did not bother to define their own subject position or explain why their biographies made them compelling petitioners. In further contrast with Gamkharashvili and his contemporaries, they addressed Khrushchev, Vasil Mzhavanadze (the first secretary of the Central Committee of Georgia's Communist Party), and Akhundov not as modern-day "benevolent tsars," but as "comrades," who were duty-bound to protect the laws of the land. Here there is a distinct lack of fawning supplicant language: toward the end of one petition, for example, the writer calls Akhundov to attention with "RESPECTED COMRADE V. AKHUNDOV!"56

These discursive patterns are echoed in the Lezgin case. The demonstrative use of appropriately "Soviet" biographies is similarly absent in archived Lezgin letters, and these writers also invoke specific laws and decrees to buttress their demands. In a 19page Rikhin Gaf complaint letter, the authors cite multiple legal provisions, including an article from the AzSSR constitution, which ensured national minorities in the republic the right to develop and use their native languages. ${ }^{57}$ Yet, the tone employed toward Akhundov in Lezgin letters is sometimes softer. One writer, for example, extensively thanks Akhundov for his intervention with the 1962 decree, before launching into a nonconfrontational explanation of why he considered it insufficient. ${ }^{58}$ Counterexamples from the Lezgin case display more continuity with supplicant styles of writing and diversify the formula that emerges from Georgian-Ingilo records at this time. 


\section{Campaigns and the Thaw}

Why did Georgian-Ingilo and Lezgin grassroots movements emerge at nearly the same time and display such similar characteristics? Georgian-Ingilo activism could be explained as a reaction to local events, such as school closures after Stalin's death, but this would not explain why broad-based activism was a possible response. Further, if we view the Georgian-Ingilo population alongside the Lezgins, then this explanation is even more incomplete. Lezgin petitioners and interviewees assert not only that Rikhin Gaf was organized simultaneously with republican attempts to nationalize the AzSSR, but also that there had been no significant changes in the Lezgin educational and cultural sphere. Crosspollination between the movements is also an unsatisfactory explanation. The Lezgins and Georgian-Ingilo who spoke with me, including some who wrote or signed petition letters, knew little about one another's activities until I broached the topic in conversation.

On the other hand, the transformative influence of World War II should not be overlooked. The war inculcated not only a sense of pride in the Soviet Union, but also a growing rights consciousness among the population. According to Zubkova (1998), Soviet social psychology changed drastically during the war. While expectations of political liberalization were dashed afterward and political consciousness may not have necessarily changed right away, she argues that the population emerged from the war less cowed than it once had been. This is the time in which many of the Georgian-Ingilo and Lezgin activists were reared, and it was into this postwar Soviet society that Khrushchev's reforms eventually were introduced, launching at least these activists out to test the limits of the regime's forbearance.

Respondents also often referenced Khrushchev when they explained why they or their neighbors decided to complain about proscribed national rights in their communities. Although general impressions of Khrushchev tended to be negative in oral history interviews - and many respondents recalled harsh food shortages during his tenure - they also acknowledged that his denunciation of the worst excesses of Stalin's regime fostered an atmosphere that favored more open and direct engagement with the state. In this vein, one former participant in Rikhin Gaf spoke to the strategic approach of group organizers:

When I joined the circle our goal was to establish lost rights, Lezgin language, culture, literature, and so on. But, well, when I joined I was very young, you understand? And Rizvanov, the others, they were older, they had finished the party school ... We didn't discuss Khrushchev or ideological things, but they knew that the time was softer. After Stalin it was good. At the time of Stalin nothing would have been possible. (Author interview, Azerbaijan, May 2011)

A leading figure in Rikhin Gaf confirmed this impression:

In the Khrushchev period there was a little leverage (rychagi), leverage that brought some release. If it had been the Stalin period they would have put us all in jail in one day! And in the Khrushchev period they didn't bother us as much, it was a bit more free ... democracy developed a little bit ... well, a type of democracy, which we used. (Author interview, Azerbaijan, April 2011)

A Georgian-Ingilo from Zaqatala similarly explained the rise of activism in his community at this time:

Then people could talk about their problems. There was a system like this: If people from my village wanted to express their opinion, they would write a letter to Baku. Then if there was no answer or reaction they would address Moscow. If the letter would get to Moscow a special commission would be formed and would contact [them] via telephone or some other way. Then they were interested in our problems. (Author interview, Azerbaijan, December 2010) 
These sentiments are strikingly similar to the recollection of a Chechen speaking about unauthorized Chechen migration from Kazakhstan to the Caucasus in 1956: "You have to grant it to Khrushchev, he didn't follow the old Russian policy of force, there was a real move at that time to get rid of the memory of Stalin, and we exploited that" (Pohl 2002, 424).

This is not to say that there were no repercussions for national agitation or to deny the ambiguity of the Thaw's contours. When asked whether it was dangerous to agitate as they did in the late 1950s and early 1960s, many former participants almost instinctively responded, "no." Yet, archives and oral histories are littered with evidence of low-level repression and arrests. One indication is that some people left their petitions and complaint letters anonymous, or openly noted their fears. For example, in the letter used to open this article, anonymous Georgian-Ingilo petitioners asked, "Why do they close our schools and if someone dares to protect the native language and native school he suffers persecution and all sorts of coercion?"59

Concrete examples of repression are also evident among Lezgins. Several people declined to discuss Rikhin Gaf with me because they still consider it to be a dangerous topic. An individual who was close to Rizvanov would not speak about Rikhin Gaf, but did say that Rizvanov isolated himself from relatives and friends in order to protect them from his activities (author interview, Azerbaijan, March 2011). Another individual, who at first characterized the Khrushchev period as being softer, in a later interview described how his association with Rikhin Gaf derailed his career. That disclosure prompted a more serious reflection. He elucidated,

There was, eh, repression did happen ... we sent several letters to Moscow with requests for help, help in the sphere of supporting Lezgin culture, development of Lezgin national culture and literature. But several people didn't like this, you understand. Therefore, there were some difficult years then. I ... I myself lived through a lot then. (Author interview, Azerbaijan, May 2011)

Archival sources provide additional examples, such as telegrams sent to Moscow asking for protection from repression for Rikhin Gaf participants and complaints about the arrests of Georgian-Ingilo activists. ${ }^{60}$ According to oral history sources, several Rikhin Gaf participants left Azerbaijan to escape repression. Rizvanov also addresses the question of repression in his written account of Lezgin national rights agitation:

There were opponents to this process [of Lezgin national rights expansion] ... All the participants were taken under control, their biographies were studied, quiet surveillance was established. Partly they ... tried to find in [participants'] creative works, in their actions, in their conversations elements contradicting Soviet morality. They thus violated their civil rights ... After interviews with workers from the KGB, many talented poets stopped their participation in "Kvatala" meetings and several others were completely scared off. (Undated samizdat, 116) ${ }^{61}$

Accounts of repression tend to blame local officials and place Moscow politicians in the role of arbiters and guarantors of stability. This is a common trope in Soviet letter writing (see Peris 2000, 110). ${ }^{62}$ Petitioners long recognized that pitting officials against one another and exploiting divisions among the powerful were effective strategies. In the Lezgin and Georgian-Ingilo campaigns, this approach appears to have worked sometimes since there are several examples of Moscow-based officials intervening on the side of petitioners.

Variable politics and experiences muddle the legacy of the Thaw. Evidence of this is abundant in these case studies. Even though many activists experienced low-level repression under Khrushchev's tenure, interviewees explicitly cite his policies as the reason why it became possible for them to assume activist roles and for their activism to take 
the forms that it did. Azerbaijani officials - perhaps taking advantage of the somewhat relaxed central control in the 1950s - implemented a series of measures promoting the role of the Azerbaijani language in the lives of all residents. Their attempts to strengthen the titular identity of the republic and to fulfill Azeri national rights were at odds, however, with the interests of some AzSSR residents who wanted to hold officials accountable for proscriptions of non-titular national rights. We see both sides play out in the $1950 \mathrm{~s}$ and early 1960s because the opening of Soviet society after Stalin's death had real meaning in everyday lives.

\section{Conclusion}

This article tells many stories. On the one hand, it offers a glimpse into the history of two non-titular communities that illustrate how national rights continued to evolve in the postWorld War II period. It also exposes the extent to which republican elites could influence the trajectories and experiences of kin communities living in neighboring republics. Of broader concern here, however, is what the Georgian-Ingilo and Lezgin rights negotiations relate about the promise of citizenship and paths of rights consciousness in the Soviet Union.

Recent publications have challenged glorifications both of the Thaw and of Khrushchev as a halcyon figure in the Soviet storm. Polly Jones, for instance, challenges depictions of the era as a "turning point" in Soviet history and highlights significant policy fluctuations between traditionalism and iconoclasm, indulging public desires and suppressing them, practicing Stalinist mindsets and enacting post-Stalinist norms. She recasts the word "Thaw," using it not to describe a definitive decline in Stalinist practices, but to capture the fragility of the period, "the potential for reversal (or 'freeze'), which each tentative forward step carried" $(2006,14)$.

This article not only embraces this ambiguity, but also emphasizes that Soviet citizens located changing possibilities for social mobilization and rights negotiation in the process of de-Stalinization. Time and again respondents criticized Khrushchev in oral history interviews, until they addressed their decision to challenge local rights norms. One Rikhin Gaf participant, for instance, recalled that he was terrified when someone asked him to help write a complaint letter about "lezgi pulu" in the 1940s, but recognized that something had intangibly shifted when he stepped into the complainant role in the late $1950 \mathrm{~s}$ (author interview, Azerbaijan, May 2011).

There is no doubt that the Soviet system failed to realize equal and full rights for its citizens, whether Georgian-Ingilo, Lezgin, or Azeri. Nonetheless, the existence of constitutionally guaranteed national rights for Soviet citizens created the possibility for people to contest formal and informal practices that proscribed their rights in this sphere. The examples of Gamkharashvili, Dzhanashvili, anonymous Lezgin petitioners, and others show us that the late Stalin period was not devoid of citizenship ideas, but we can also identify a shift in the methods and results of subsequent challenges to the boundaries of Soviet citizenship.

Activists in the late 1950s and early 1960s were part of broader grassroots movements that displayed a sense of strength and confidence that was absent in earlier efforts. They also relied less explicitly on the clout of sympathetic elites in kin republics to give meaning to ascribed rights. Charkviani's interventions on behalf of the Georgian-Ingilo population resulted in an inter-republic agreement and temporary reversals of informal policies (and Lezgin contemporaries achieved no such promises), but the Azerbaijani Communist Party issued a series of official decrees in the 1960s in response to Georgian-Ingilo and 
Lezgin grassroots rights claims. The decrees may not have been fully realized, but these activists did manage to succeed in a rights negotiation with the state during Khrushchev's tenure in office.

\section{Notes}

1. The research and writing of this article were made possible by support from the US Department of Education's Fulbright-Hays Program, the Social Science Research Council, and the University of Michigan. Earlier versions of this article were presented to the 2012 SSRC Eurasia Program DDA Fellows Workshop at Georgetown University and to the Soviet Nationalities Question after 1945 Symposium at the University of Toronto. I am grateful to these workshop participants, to the editor and anonymous readers of Nationalities Papers, and to Douglas Northrop, Ronald Suny, Bruce Grant, Golfo Alexopoulos, James von Geldern, Ian Campbell, and Claire Pogue Kaiser for their suggestions. Thanks also to Zbigniew Wojnowski for organizing and editing this issue. For the epigraph, see Azərbaycan Respublikası Prezidentinin İşlər İdarəsinin Siyasi Sənədlər Arxivi, Baku (hereafter ARPIISSA) f.1, op.48, d.405, 1.90.

2. Work stoppages and other acts of protest occurred in the late Stalin era as well, but behaviors evolved over time. By the late 1950s, the CPSU Central Committee had approved the return of exiled Chechens, Ingush, Balkars, Karachays, and Kalmyks and reconstituted their republics, but failed to similarly rehabilitate others such as the Crimean Tatars (Pohl 2002; Westren 2012, $331-430)$.

3. There is no agreement about the definition and use of the terms Ingilo and Georgian to describe this population. The anonymous petitioners in the epigraph, for example, identify themselves as "Mohammedans" [magometane] from "Ingilo" villages. They also specify that they consider themselves to be part of the Georgian narod (ARPIISSA f.1, op.48, d.405, 11.89-93). Moscow-based and Georgian ethnographers generally categorize this population as an ethnographic group of the Georgian nation. For example, ethnographer N.G. Volkova defined "Ingilo" as a term used by Ingilo people and Azerbaijanis to refer to the "Georgian population" of northwest Azerbaijan (1977, 87). Azerbaijani scholars tend to emphasize differences between Georgian and Georgian-Ingilo origins and favor the Ingilo ethnonym. I use the term "GeorgianIngilo" here in order to be inclusive of the different ways in which people have identified themselves to me and in archived petitions - including as Ingilo, Georgian, Azerbaijani Georgian (Ingilo), and Georgian-Ingilo.

4. Soviet censuses put the number of Georgians in Azerbaijan at 10,196 in 1939 (Vsesoiuznaia perepis' naseleniia 1939 goda 1992, 71) and 9526 in 1959 (Tsentral'noe statisticheskoe upravlenie SSSR 1963,134-135). These numbers probably only account for Christian Georgian-Ingilo settlements and Georgians elsewhere in the AzSSR as the Muslim Georgian-Ingilo population generally was categorized as Azerbaijani in Soviet passports and censuses. Other population estimates are similarly vague and inconsistent. In 1924, for example, Liaister and Chursin documented 15,000 "Ingilo" (also called Zaqatala Georgians and Georgian-Muslims in the text) in Azerbaijan (1924, 282). In 1944, the first secretaries of Azerbaijan and Georgia, Mir Cafar Bagirov and Kandid Charkviani, reported to Stalin that there were 8147 "Ingilo" persons in Qax, Balakan, and Zaqatala (sak'art'velos šinagan sak'met'a saministros ark'ivi II, Tbilisi [hereafter, sšssa (II)], f.14. op.18. d.180. 1.5). An undated document likely produced in the late 1950s or early 1960s for the Central Committee of Azerbaijan's Communist Party reported that there were 6000 "Ingilo" in Azerbaijan, but it is unclear who it counted as "Ingilo" (ARPIISSA, f.1, op.48, d.405, 1.38). In the late 1970s, meanwhile, ethnographer Volkova reported that 5000 "Georgians" lived in the "Qaxingilo" administrative area of the Qax region $(1977,88)$.

5. This article is based on archival research and more than 120 oral history interviews that I conducted between 2007 and 2013. I briefly worked with documents about Soviet nationality policies in the archive of Azerbaijan's Communist Party (ARPIISSA) in 2008, but archive employees informed me that my research topic was no longer permitted in later trips. The archival records of Georgia's Communist Party proved valuable for this project, but the Lezgin case is not richly documented outside of Azerbaijan. A search of available files in the Central State Archive of the Republic of Dagestan turned up few documents about Lezgins in Azerbaijan. This indicates a lower level of kin republic support for Lezgins and is in line with information that I collected in oral history interviews. 
6. For the Muscovite period, see Kivelson (2002) and Kollmann (1999).

7. Marshall's definition of citizenship, for example, has been used to evaluate the Soviet case (Marshall 1964, cited in Alexopoulos 2006, 495 and in Varga-Harris 2006, 114). Alexopoulos, for example, juxtaposes Soviet citizenship with Marshall's triad of civil, political, and social protections and finds that only social citizenship (or "the right to a modicum of economic welfare and security") was meaningful in the USSR since economic rights there were "reasonably protected" (2006, 495). Alexopoulos notes, however, that European and American citizenships also have fallen short of "the modern ideal of an equality of citizens" $(2006,487)$.

8. This resonates with Kozlov's argument that mass disturbances in the post-Stalin years often reflected popular investment in the Soviet system rather than anti-regime or anti-Communist dissent (Kozlov 2002). Kevin O'Brien formulated the notion of "rightful resistance" in his work on China, but it is also helpful for thinking about the Soviet case. According to O'Brien, rightful resistance

entails the innovative use of laws, policies, and other officially promoted values to defy 'disloyal' political and economic elites; it is a kind of partially sanctioned resistance that uses influential advocates and recognized principles to apply pressure on those in power who have failed to live up to some professed ideal or who have not implemented some beneficial measure. $(1996,33)$

9. Margaret Somers's approach to citizenship is productive for theorizing Soviet citizenship. Somers foregrounds the localized and uneven nature of rights regimes and explores the "relational settings of contested but patterned relations among people and institutions" that shape citizenship formation $(1998,161)$. She further draws on Hannah Arendt and Earl Warren to define citizenship as "the right to have rights," with access to political and social membership serving as baseline parameters (Somers 2008, 5-6).

10. Given the delayed pace of non-titular national cultural development and minority region indigenization in the 1920s and 1930s, many Georgian-Ingilo schools were switched from Azerbaijanito Georgian-language instruction only in 1937 and 1938. This means that they functioned as Georgian-language schools for just a few years before being converted back to Azerbaijanilanguage schools in the early 1940s (sšssa (II), f.14. op.18. d.180. 1.6).

11. Georgian archives contain complaint letters and informational reports written by a few other individuals. For example, Archil Gavrilovich Dzhanashvili was from Qax, built his career in Tbilisi, and sent the Georgian government lengthy reports explaining why Balakan, Qax, and Zaqatala should be transferred to Georgia (sšssa [II], f.14, op.18, d.180, 11.46-94).

12. See, for example, sšssa (II), f.14, op.20, d.271, 1.2; sšssa (II), f.14, op.24, d.296, 1.1.

13. People in Zaqatala, Qax, and Balakan frequently talked about Gamkharashvili's activism in oral history interviews.

14. Cited pages translated for the author from Georgian to Russian by Timothy Blauvelt. Charkviani came to know Gamkharashvili either in person or through the complaint letters that Gamkharashvili sent him, but does not seem to know Gamkharashvili in the early part of the 1940s. For instance, in a letter to Charkviani and Valerian Bakradze, the Chairman of the Georgian Sovnarkom, in 1943, Gamkharashvili introduces himself by claiming acquaintance with Comrade S. Khoshtari (sšssa [II], f.14, op.18, d.180, 1.31). He might be referring to Semyon Khostaria, a deputy in the Council of Nationalities (Sovet natsional'nostei).

15. Ibid., 11.5-7.

16. Azərbaycan Respublikası Dövlət Arxivi, Baku [hereafter, ARDA] f.411, op.25, d.521, 1.156, and ARPIISSA f.1, op.220, d.50, 11.22-23. The latter document is cited in Gasanly (2008, 461-464).

17. Gosudarstvennyi arkhiv Rossiiskoi Federatsii, Moscow [hereafter, GARF] f.3316, op.29, d.576, 1.2 .

18. GARF f.3316, op.29, d.576, 1.3 .

19. I did not find evidence of an official "lezgi pulu" policy, but various sources indicate that it was an informal practice in Azerbaijan. "Lezgi pulu" is a pointed topic in myriad oral history interviews, in a lengthy complaint letter written by a group of Lezgin poets, writers, teachers, and other cultural figures in 1963 (ARPIISSA f.1, op.56, d.38, 1.372), and in a short book of Lezgin history written in 1990 by a Lezgin activist and his son (Rizvanov and Rizvanov 1990, 30). I also heard similar stories in oral history interviews that I conducted with people from other national communities in Azerbaijan. For example, Lezgins complain that they had to pay a special fee to attend school if they did not change their registered nationality to Azerbaijani. A Lak woman 
from Zaqatala, meanwhile, recounted that she and other students from "Dagestani" nationalities could attend Azerbaijani-language schools for free in the 1940s, but had to pay a special fee to enroll in the local Russian-language school.

20. Vasil Mzhavanadze - who became first secretary of the Georgian SSR in 1953 and stayed on until 1972 - was Georgian, but was something of an outsider in the republic. He developed his political career in Ukraine and was one of Khrushchev's protégés.

21. Not long after Beria's execution in December 1953, Bagirov was expelled from the Party and arrested, charged with supporting anti-Soviet elements and condemned for his close relationship with Beria. Bagirov was executed in 1956.

22. Hasanli is transliterated as Gasanly in citations for his Russian-language publications.

23. ARPIISSA f.1, op.46, d.110, 11.324-325.

24. ARPIISSA f.1, op.53, d.36, 1.123 .

25. ARPIISSA f.1, op.48, d.405, 1.72 .

26. Ibid., 1.4.

27. Ibid., 1.138 .

28. Azərbaycan Respublikası Dövlət Arxivinin Şəki filialı, Shaki (hereafter, ARDA SF), f.201, op.1, d.202, 1.286. The name of Qax-Gurcu was later changed to Qax-Ingilo.

29. ARPIISSA f.1, op.46, d.110, 11.316-319.

30. ARDA f.411, op. 8, d.536, 1.58 .

31. Ibid., 11.59-61.

32. ARPIISSA f.1, op. 48 , d.405, 11.58-59.

33. Ibid., 1.6. No date is given in the document, but the content suggests it was written in 1962 or 1963.

34. Ibid., 11.129-130, and Ibid., 11.123-126. This was a common narrative in oral history interviews, including one that I conducted with a former school inspector, who detailed ways in which enrollments in Georgian school sectors were underreported and parents were pressured to enroll their children in Azerbaijani sectors.

35. Ibid., 1.8 .

36. ARPIISSA f.1, op.53, d.36, 11.127-128.

37. Ibid., 11.129-134.

38. Azerbaijan government reports from the 1960s hint at the widespread nature of agitation about Georgian-Ingilo national rights after school conversions began in 1954, but archives also preserved petitions sent in the 1960s from Tbilisi student dorms, Zayam, Mosul, Qax-Gurcu (which later became Qax-Ingilo), Aliabad, and elsewhere. See, for example, ARPIISSA f.1, op.48, d.405, 1.86; Ibid., 11.100-104.

39. Khrushchev called for a return to socialist legality in his Secret Speech. It was a euphemism for due process, stronger legal institutions, and better adherence to laws and legal norms.

40. Rikhin Gaf (known as Serdechnoe Slovo in Russian) first met on 18 October 1959, and functioned until 1988 (Rizvanov [undated samizdat], 115).

41. ARPIISSA f.1, op.56, d.38, 11.357-360. The Lezgin decree was adopted in August 1962.

42. Azərbaycan Respublikası Dövlət Odəbiyyat və İncəsənət Arxivi, Baku (hereafter, ARDAIA), f.340, op.1, d.990, 11.39-40.

43. ARPIISSA f.1, op.56, d.38, 1.348 .

44. For example, Pyle shows that peasants seeking state assistance during World War I both invoked specific legal rights and appealed to informal "rules" or moral principles $(1997,60)$. In her study of housing petitions in Khrushchev-era St. Petersburg, Varga-Harris argues that a new mode of negotiation developed during the Thaw, but also finds that complainants in her study often blurred the lines between supplicant and citizen $(2006,111)$.

45. Fitzpatrick also identifies a citizen type who invokes a language of rights; criticizes policies, officials, or miscarriages of justice; and denies, underplays, or conceals personal motives connected to the complaint, but this type is underdeveloped in comparison with her supplicant profile (1996, 104).

46. sšssa (II), f.14, op.18, d.161, 11.1-19.

47. For example, sšssa (II), f.14, op.20, d.271, 1.5.

48. Ibid., 1.13.

49. sšssa (II), f.14, op.18, d.180, 1.30 .

50. sšssa (II), f.14, op.20, d.271, 1.2.

51. sšssa (II), f.14, op.18, d.180, 1.31 . 
52. Ibid., 11.74-94. Saingilo is the term that many Georgian-Ingilo and Georgians use to describe the three regions where Georgian-Ingilo live in Azerbaijan.

53. ARPIISSA, f.1, op.48, d.405, 11.79-80.

54. Ibid., 1.100.

55. Ibid., 1.144. Akhundov replaced Mustafaev in 1959.

56. Ibid., 1.143.

57. ARPIISSA, f.1, op.56, d.38, 1.373 .

58. Ibid., 1.333.

59. ARPIISSA, f.1, op.48, d.405, 1.90 .

60. ARPIISSA, f.1, op.56, d.38, 1.366; ARPIISSA, f.1, op.48, d.405, 11.141-144.

61. Several people recounted comparable narratives in oral history interviews, but Rizvanov provides the most complete description of repression directed against participants. Khvathal [КІватІал] was an informal name for Rikhin Gaf.

62. Peris links this pattern to a long-standing belief in the benevolence of authority figures, but finds in his case that central officials often forwarded the complaints to local officials instead of resolving them.

\section{Bibliography}

Alexopoulos, Golfo. 1997. "The Ritual Lament: A Narrative of Appeal in the 1920s and 1930s." Russian History/Histoire Russe 24 (1-2): 117-129.

Alexopoulos, Golfo. 2006. "Soviet Citizenship, More or Less: Rights, Emotions, and States of Civic Belonging." Kritika: Explorations in Russian and Eurasian History 7 (3): 487-528.

Allworth, Edward. 1998. The Tatars of Crimea: Return to the Homeland. Durham: Duke University Press.

Azərbaycan Respublikası Dövlat Arxivi. ARDA, Republic of Azerbaijan State Archive, Baku.

Azərbaycan Respublikası Dövlət Arxivinin Şəki filialı. ARDA SF, Shaki branch of the Republic of Azerbaijan State Archive, Shaki.

Azərbaycan Respublikası Dövlət Odəbiyyat və İncəsənət Arxivi. ARDAIA, Republic of Azerbaijan State Literature and Art Archive, Baku.

Azərbaycan Respublikası Prezidentinin İşlər İdarəsinin Siyasi Sənədlər Arxivi. ARPIISSA, Archive of Political Documents of the Administrative Department of the President of the Republic of Azerbaijan, Baku.

Balaev, Aidyn. 2005. Etnoiazykovye protsessy v Azerbaidzhane v XIX-XX vv. Baku: Nurlar.

Brubaker, Rogers. 1996. Nationalism Reframed: Nationhood and the National Question in the New Europe. Cambridge: Cambridge University Press.

Burbank, Jane. 2006. "An Imperial Rights Regime: Law and Citizenship in the Russian Empire." Kritika: Explorations in Russian and Eurasian History 7 (3): 397-431.

Charkviani, Kandid. 2004. Gentsdili da naazrevi. Tbilisi: Merani.

Chulos, Chris J. 1997. "Peasants' Attempts to Reopen their Church, 1929-1936." Russian History/ Histoire Russe 24 (1-2): 203-213.

Fisher, Alan. 1978. The Crimean Tatars. Stanford: Hoover Institution Press.

Fitzpatrick, Sheila. 1994. Stalin's Peasants: Resistance and Survival in the Russian Village After Collectivization. New York: Oxford University Press.

Fitzpatrick, Sheila. 1996. "Supplicants and Citizens: Public Letter-Writing in Soviet Russia in the 1930s." Slavic Review 55 (1): 78-105.

Gasanly, Dzhamil'. 2008. SSSR-Turtsiia: ot neitraliteta k kholodnoi voine (1939-1953). Moscow: Tsentr Propagandy.

Gasanly, Dzhamil'. 2009. Khrushchevskaia “ottepel"” i natsional'nyi vopros v Azerbaidzhane (1954-1959). Moscow: Flinta.

Gosudarstvennyi arkhiv Rossiiskoi Federatsii (GARF, State Archive of the Russian Federation), Moscow.

Jones, Polly. 2006. "Introduction: the dilemmas of de-Stalinization." In The Dilemmas of DeStalinization: Negotiating Cultural and Social Change in the Khrushchev Era, edited by Polly Jones, 1-18. London: Routledge.

Kivelson, Valerie. 2002. "Muscovite 'Citizenship': Rights without Freedom.” The Journal of Modern History 74 (3): 465-489. 
Kollmann, Nancy. 1999. By Honor Bound: State and Society in Early Modern Russia. Ithaca: Cornell University Press.

Kozlov, Vladimir. 2002. Mass Uprisings in the USSR: Protest and Rebellion in the Post-Stalin Years. London, NY: M.E. Sharpe.

Liaister, A. F., and G. F. Chursin. 1924. Geografiia Kavkaza: priroda i naselenie. Tiflis: Izdanie Zakavk. Kommunist. Universitet. Imeni 26.

Marshall, T. H. 1964. Class, Citizenship, and Social Development. New York: Doubleday.

O’Brien, Kevin J. 1996. "Rightful Resistance." World Politics 49 (1): 31-55.

Peris, Daniel. 2000. "'God is Now on Our Side': The Religious Revival on Unoccupied Soviet Territory during World War II." Kritika: Explorations in Russian and Eurasian History 1 (1): $97-118$.

Pohl, Michaela. 2002. "'It Cannot be that Our Graves Will be Here': The Survival of Chechen and Ingush deportees in Kazakhstan, 1944-1957." Journal of Genocide Research 4 (3): 401-430.

Pyle, Emily. 1997. "Peasant Strategies for Obtaining State Aid: A Study of Petitions During World War I." Russian History/Histoire Russe 24 (1-2): 41-64.

Rizvanov, Zabit. Undated. Kniga pravdy: sbornik statei 1980-90 gg. Qusar: samizdat.

Rizvanov, Zabit, and Rizvan Rizvanov. 1990. Istoriia lezgin (kratkii nauchno-populiarnyi ocherk). Makhachkala: Obshchestvo Knigoliubov Dagestana.

sak'art'velos šinagan sak'met'a saministros ark'ivi II (sšssa [II], Ministry of Internal Affairs of Georgia Archive II), Tbilisi.

Somers, Margaret. 1998. "Rights, Relationality, and Membership: Rethinking the Making and Meaning of Citizenship." In Public Rights, Public Rules: Constituting Citizens in the World Polity and National Policy, edited by Connie L. McNeely, 153-206. New York and London: Garland Publishing.

Somers, Margaret. 2008. Genealogies of Citizenship: Markets, Statelessness, and the Right to have Rights. New York: Cambridge University Press.

Tsentral'noe statisticheskoe upravlenie SSSR. 1963. Itogi Vsesoiuznoi perepisi naseleniia 1959 goda: Azerbaidzhanskaia SSR. Moscow: Gosstatizdat.

Tsentral'noe statisticheskoe upravlenie SSSR. 1973. Itogi Vsesoiuznoi perepisi naseleniia 1970 goda. 4 vols. Moscow: Statistika.

Tsentral'nyi gosudarstvennyi arkhiv Respubliki Dagestan (TsGARD, Central State Archive of the Republic of Dagestan), Makhachkala.

Uehling, Greta Lynn. 2004. Beyond Memory: The Crimean Tatars' Deportation and Return. New York: Palgrave Macmillan.

Varga-Harris, Christine. 2006. "Forging Citizenship on the Home Front: Reviving the Socialist Contract and Constructing Soviet Identity During the Thaw." In The Dilemmas of DeStalinization: Negotiating Cultural and Social Change in the Khrushchev Era, edited by Polly Jones, 101-116. London: Routledge.

Viola, Lynne. 1996. Peasant Rebels under Stalin: Collectivization and the Culture of Peasant Resistance. New York: Oxford University Press.

Volkova, N. G. 1979 (1977). “Ingilo.” In Polevye issledovaniia Instituta etnografii, 87-96. Moscow: Nauka.

Vsesoiuznaia perepis' naseleniia 1939 goda: Osnovnye itogi. 1992. Moscow: Nauka.

Westren, Michael Herceg. 2012. "Nations in Exile: 'The Punished Peoples' in Soviet Kazakhstan, 1941-1961." PhD diss., University of Chicago.

Williams, Brian G. 2001. The Crimean Tatars: The Diaspora Experience and the Forging of a Nation. Leiden: Brill.

Zubkova, Elena. 1998. Russia After the War: Hopes, Illusions and Disappointments, 1945-1957. Armonk, NY: M.E. Sharpe. 